\title{
EFFECT OF SKIPPING IRRIGATION AND SOWING METHODS ON YIELD AND ITS COMPONENTS OF FOUR BREAD WHEAT CULTIVARS \\ El-Seidy, E. H. ${ }^{\star}$; A. M. Moussa ${ }^{* *}$; U. A. Abd El-Razek ${ }^{\star}$ and M. O. Al-Farouk \\ "Department of Agronomy, Fac. of Agric., Tanta University. \\ "Wheat Research Depart., Field Crops Research Inst., ARC.
}

\begin{abstract}
Two field experiments were conducted at Gemmeiza Agric. Res. Stat. during $2011 / 12$ and $2012 / 13$ growing seasons, to study the influence of different irrigation regimes i.e. irrigation at tillering stage $\left(I_{1}\right)$, at tillering and heading stage $\left(I_{2}\right)$ and at tillering, heading and grain filling stage $\left(I_{3}\right)$ with three methods of sowing i.e. broadcasting, drilling and beds sowing on yield and its components of four wheat cultivars namely Gemmeiza-11, Misr-1, Shandaweel-1 and Sids-12.A significant reductions in grain and straw yields in both seasons was obtained as a result to subjecting wheat plants to drought-stress. Results showed that three irrigations increased significantly number of spikes $/ \mathrm{m}^{2}$, number of grains/spike, 1000-grain weight, grain weight/spike, biological yield and harvest index except protein content. It could be noticed beds sowing method gave highest yield components. Gemmeiza-11 wheat cultivar surpassed the other tested cultivars concerning with the above mentioned traits, except number of spikes $/ \mathrm{m}^{2}$ and straw yield. While, Misr-1 surpassed in no. of spikes in both seasons and harvest index in the second season, however, Shandaweel-1 produced the highest protein content. A significant interactions between the effect of irrigation (I), sowing methods $(M)$ and wheat cultivars (V) were found in increasing the yield and its components, except between irrigation and sowing methods $(\mathrm{I} \times \mathrm{M})$ concerning with grain weight/spike $(\mathrm{g})$, grain yield (ardab/fad), straw yield (ton/fad) and biological yield (ton/ fad) in the second season only. Correlation positive and significant relationships between grain yield/fad and all yield components.

It could be concluded that to get highest productivity of wheat under middle delta region conditions it must cultivate Gemmeiza-11 cultivar with addition of three irrigations with using the beds sowing method.

Keywords: Bread wheat cultivars, number of irrigations, water stress, sowing methods, grain yield and its components.
\end{abstract}

\section{INTRODUCTION}

Common bread wheat (Triticum aestivum L.) is one of the most important crops in the world, it forms more than $40 \%$ of the world's stable food (Coventry et al., 2011). Bread wheat and durum wheat ((Triticum durum Dest.) contribute a total of $90 \%$ of the world's wheat production and they are grown on approximately $17 \%$ of the world's cultivated land, covering over 200 million hectares. The gap between the local production and consumption is continuously increased due to increasing the country population with limited cultivated area. So, increasing wheat production, either horizontal or vertical, through scientific basis is a national target. Cultivating it in the newly reclaimed soils with drought tolerant cultivars under modern irrigation 
systems and sowing methods, will be increase wheat production horizontally. Meanwhile, cultivation of high yielding cultivars and applying the proper agronomic practices mean increasing wheat production vertically.

Water requirement is the most important and limiting practice affecting wheat production in arid and semi-arid regions. So, irrigation optimizing i.e. applying the irrigation water timely and quantitatively will increase wheat yield and save water as well and increasing water use efficiency. It is well known that the crop productivity is a function of soil moisture availability during the growing season. Moussa and Abd ElMaksoud (2004) reported that number of spikes $/ \mathrm{m}^{2}, 1000$-grain weight, straw and grain yields were reduced due to irrigation after higher soil moisture depletion. Salem, Nagwa et al. (2006) reported that the adopted treatments i.e. irrigation regimes and wheat cultivars exerted significant effects for all characters under study.

Sowing methods i.e. broadcast method, drilling and raised beds is one of the important factors influencing of wheat production increase. Broadcast seeding, the oldest and simplest method, is widely used in regions where modern have not been introduced. Drilling saves seed, insures better germination and more uniform stands, reduces winter injury and almost always produces better yields. Plant on raised beds prevented lodging of wheat plants compared to flat planting. Meanwhile, saving about $27 \%$ of irrigation water, saving 30-50\% of rate and fertilizer efficiency increased and led to increases in grain yield (Sayre and Ramos, 1997) in addition, to providing the fuel needed to run irrigation machines $(1.5 \mathrm{~h} / \mathrm{f}$ X $18 \mathrm{~L}$.E the cost of $10 \mathrm{~L} /$ solar $\})=27$ (L.E /fad). The objectives of this investigation were aimed to study the influence of irrigation water regimes and three sowing methods on yield and its components and protein content of four Egyptian bread wheat cultivars namely Gemmeiza-11, Misr-1, Shandaweel-1 and Sids12.

\section{MATERIALS AND METHODS}

Field experiment:

This investigation was carried out at El-Gemmeiza Agric. Res. Stat, A.R.C., El- Gharbya Governorate, Egypt, during 2011/12 and 2012/13 growing seasons to study the effect of three irrigation regimes and three sowing methods on yield and yield components and protein content of four bread wheat cultivars (Triticum aestivum L.). A split-split- plot design with four replications was adopted, the main plots were three irrigation regimes i.e. irrigation at tillering stage $\left(I_{1}\right)$, at tillering and heading stage $\left(I_{2}\right)$ and at tillering, heading and grain filling stage $\left(I_{3}\right)$, while the three sowing methods i.e. broadcasting, drilling and beds sowing were assigned in the sub- plots and four wheat cultivars as sub- sub- plots Table 2. Sowing dates were $20^{\text {th }}$ November in the first season and $25^{\text {th }}$ November in the second growing season. The plot area was $8.4 \mathrm{~m}^{2}$ i.e. 2.4 width and $3.5 \mathrm{~m}$ in length. Seventy units of nitrogen (urea $46 \%$ ) were added in two equal portions, the first before the first irrigation and the rest was applied before the second irrigation. Phosphate fertilizer was applied at the rate of $100 \mathrm{~kg}$ calcium 
superphosphate/fad $\left(15.5 \mathrm{P}_{2} \mathrm{O}_{5}\right)$ during seedbed preparation . The preceding crop was cotton in both seasons. The crop was harvested during the third week of May 2011 and 2012, respectively. The experimental treatments were:

Table 1: Date and quantity of irrigation water and accumulated water applied $(\mathrm{mm})$ under different irrigation regimes in 2011/12 and 2012/13 seasons.

\begin{tabular}{|c|c|c|c|c|c|c|c|}
\hline $\begin{array}{l}\text { Preceding } \\
\text { crop }\end{array}$ & \begin{tabular}{|c} 
Irrigation \\
regimes
\end{tabular} & $\begin{array}{c}\text { Sowing } \\
\text { date }\end{array}$ & $\begin{array}{l}\text { Mohayah } \\
\text { irrigation }\end{array}$ & $\begin{array}{c}1^{\text {st }} \\
\text { irrigation }\end{array}$ & \begin{tabular}{|c|}
$2^{\text {nd }}$ \\
irrigation
\end{tabular} & $\begin{array}{c}3^{\text {rd }} \\
\text { irrigation }\end{array}$ & $\begin{array}{l}\text { Accumulation } \\
\text { water applied }\end{array}$ \\
\hline \multicolumn{8}{|c|}{ 2011/12 season } \\
\hline \multirow{6}{*}{ Cotton } & $l_{1}$ Date & $20 / 11 / 2011$ & $11 / 12 / 2011$ & $16 / 2 / 2012$ & - & - & \\
\hline & $\mathrm{Q}(\mathrm{mm})$ & 156.8 & 92.3 & 233.0 & - & - & 482.1 \\
\hline & $I_{2}$ Date & $20 / 11 / 2011$ & $11 / 12 / 2011$ & 9/2/2012 & $10 / 3 / 2012$ & - & \\
\hline & $\mathrm{Q}(\mathrm{mm})$ & 156.8 & 92.3 & 168.3 & 135.4 & - & 552.8 \\
\hline & $I_{3}$ Date & $20 / 11 / 2011$ & $11 / 12 / 2011$ & $25 / 1 / 2012$ & $3 / 3 / 2012$ & $2 / 4 / 2012$ & \\
\hline & $\mathrm{Q}(\mathrm{mm})$ & 156.8 & 92.3 & 111.2 & 123.8 & 106.0 & 590.1 \\
\hline \multicolumn{8}{|c|}{ 2012/13 season } \\
\hline \multirow{6}{*}{ Cotton } & $l_{1}$ Date & $25 / 11 / 2012$ & 17/12/2012 & $19 / 3 / 2013$ & - & - & \\
\hline & $\mathrm{Q}(\mathrm{mm})$ & 106.6 & 103.3 & 224.4 & - & - & 434.3 \\
\hline & $I_{2}$ Date & $25 / 11 / 2012$ & $17 / 12 / 2012$ & $17 / 2 / 2013$ & $1 / 4 / 2013$ & - & \\
\hline & $\mathrm{Q}(\mathrm{mm})$ & 106.6 & 103.3 & 120.4 & 115.0 & - & 445.3 \\
\hline & $I_{3}$ Date & $25 / 11 / 2012$ & $17 / 12 / 2012$ & $27 / 1 / 2013$ & $29 / 2 / 2013$ & $2 / 4 / 2013$ & \\
\hline & $\mathrm{Q}(\mathrm{mm})$ & 106.6 & 103.3 & 91.3 & 118.1 & 99.3 & 518.6 \\
\hline
\end{tabular}

A. Three irrigation regimes (I):

$I_{1}=$ One irrigations i.e. at tillering stage, $I_{2}=$ Two irrigations i.e. at tillering and heading stage and $I_{3}=$ Three irrigations i.e. at tillering, heading and grain filling stage and accumulation water applied were applied as shown in Table 1. Irrigation water was delivered to the plots through a circular orifice and water quantity was measured using the formula of immersed orifice according to (James, 1988) as follows:

$$
Q=0.61 \times 0.443 \times A \sqrt{h}
$$

Where:

$\mathrm{Q}=$ Orifice discharge, $\mathrm{L} / \mathrm{sec}$. $\quad \mathrm{A}=$ Area of orifice, $\mathrm{cm}^{2}$.

$h=$ Effective water head over the orifice center $(m)$.

$B$. Three sowing methods $(M)$ :

$M_{1}=$ Broadcasting method, $M_{2}=$ Drilling method and $M_{3}=$ Beds method.

C.Wheat cultivars (V):

$\mathrm{V}_{1}=$ Gemmeiza-11, $\mathrm{V}_{2}=$ Misr $-1, \mathrm{~V}_{3}=$ Shandaweel -1 and $\mathrm{V}_{4}=$ Sids -12

The pedigree of the four studied cultivars are shown in Table 2.

The studied traits:

1. Yield and yield components: Number of spikes $/ \mathrm{m}^{2}$, Number of grains/spike, Grain weight/spike (g), 1000-grain weight (g), Grain yield (ardab/fad), Straw yield (ton/fad), Biological yield (ton/ fad), Harvest index (\%) and Grain protein content (\%).

2. Simple correlation coefficients analysis: A matrix of simple correlation coefficients between grain yield and its attributes were computed according to Kearsey and Pooni (1996). 


\section{Statistical analysis:}

The obtained data were subjected to statistical analysis of variance as described by Snedecor and Chochran (1981) and treatment means were compared by least significant difference (L.S.D.) at $5 \%$ and $1 \%$ level of probability.

Table 2: The used cultivars and its pedigree.

\begin{tabular}{|c|c|c|c|}
\hline No. & Cultivar name & Pedigree & $\begin{array}{c}\text { General } \\
\text { characteristics }\end{array}$ \\
\hline 1 & Gemmeiza-11 & $\begin{array}{c}\text { Bow"s"/Kvz"//7c/seri82/3/Giza168/Sakha61. } \\
\text { GM7892-2GM-1GM-2GM-1GM-0GM. }\end{array}$ & $\begin{array}{c}\text { White grains } \\
\text { High tillering } \\
\text { Resistant to yellow rust } \\
\text { Resistant to leaf rust }\end{array}$ \\
\hline 2 & Sids-12 & \begin{tabular}{|c|} 
BUC//7C/ALD/5/MAYA74/ON//1160- \\
147/3/BBGLL/4/HAT"S"/6/MAYA/VUL/CMH74A.6 \\
30/4*SX. \\
SD7096-4SD-1SD-1SD-0SD.
\end{tabular} & $\begin{array}{c}\text { Red grains } \\
\text { Medium tillering } \\
\text { Resistant to yellow rust } \\
\text { Susceptible to leaf rust }\end{array}$ \\
\hline 3 & Misr-1 & $\begin{array}{c}\text { OASIS/KAUZ//4*BCN/3/2*PASTOR. } \\
\text { CMss00Y01881T-050M-030Y-030M-030WGY- } \\
\text { 33M-0Y-0S. }\end{array}$ & $\begin{array}{c}\text { White grains } \\
\text { High tillering } \\
\text { Resistant to yellow rust } \\
\text { Resistant to leaf rust }\end{array}$ \\
\hline 4 & Shandaweel-1 & SITE//MO/4/NAC/TH.AC//3*PVN/3/MIRLO/BUC. & $\begin{array}{c}\text { Red grains } \\
\text { Low tillering } \\
\text { Susceptible to yellow } \\
\text { rust } \\
\text { Susceptible to leaf rust }\end{array}$ \\
\hline
\end{tabular}

\section{RESULTS AND DISCUSSION}

\section{A. Effect of irrigation numbers (I).}

Results in Table 3 clearly showed that three irrigations significantly increased the number of spikes $/ \mathrm{m}^{2}\left(429.67\right.$ and $441.33 \mathrm{spikes} / \mathrm{m}^{2}$, respectively) compared to one irrigation $\left(I_{1}\right)$ and two irrigations $\left(I_{2}\right)$. Also, the highest number of grains/spike (69.08 and 74.25) and the highest values of 1000 -grain weight $(57.66$ and $60.31 \mathrm{~g})$ as compared with two irrigations $(54.63$ and $56.43 \mathrm{~g})$ and one irrigation $\left(\mathrm{I}_{1}\right)$, which recorded (48.88 and $51.79 \mathrm{~g}$ ) in both seasons, indicating that the three irrigation regimes behaved differently for these characters. Moustafa et al. (1996) and Ali et al. (2012) found that increasing grains number/spike was correlated with increasing of irrigation frequency and also when Appling the irrigation water timely and quantitively will increase yield and its attributes. Water deficiency and high temperature during grain filling period of wheat is considered a great stress caused reduction in this trait. These results are in agreement with those obtained by Abdelraouf et al. (2013), Genedy (2014) and El- Hag,Walaa (2015).

Results in Table 4 indicate a significant increase in grain weight/spike, grain yield in (ardab/fad), straw yield in (ton/fad.) and biological yield in (ton/ fad.) with increasing of irrigation numbers. Three irrigations showed the highest values of grain weight/spike (3.61and $4.64 \mathrm{~g}$ ) compared to the other two treatments $\left(I_{1}\right.$ and $\left.I_{2}\right)$, the highest values of grain yield (23.24 and23.54 ardab/ fad.), straw yield (5.62 and 6.25 ton/fad.) and biological yield (9.11 and 9.78 ton/ fad.) in both seasons, respectively. (Awad 2001) studied the risk of irrigation water deficit on wheat yield by skipping one watering 
through tillering, heading and flowering compared with full irrigation. The results revealed that, deficit irrigation at all stages leads to significant reduction in straw and grain yields compared with full irrigation. The increases in grain yield under $\left(\mathrm{I}_{3}\right)$ irrigation scheme amounted to 19.42 and $7.60 \%$ in $2011 / 12$ and 10.41 and $3.84 \%$ in 2012/13, comparable with those under $\left(I_{1}\right)$ and $\left(I_{2}\right)$ schemes, respectively. This reduction may be due to the effect of water deficit on pollination and fertilization processes, which lead to decreasing grains per spike and it attributed to reducing seed set under water stress condition. These results are in Abdelraouf et al. (2013).

Table 3: Effects of irrigation numbers, sowing methods and wheat cultivars and its interactions on number of spikes $/ \mathrm{m}^{2}$, number of grains/spike and 1000-grain weight $(\mathrm{g})$ during the two seasons, 2011/12 and 2012/13.

\begin{tabular}{|c|c|c|c|c|c|c|}
\hline \multirow{2}{*}{\begin{tabular}{|l|} 
Characters \\
Treatments
\end{tabular}} & \multicolumn{2}{|c|}{$\begin{array}{c}\text { Number of spikes } \\
/ \mathrm{m}^{2}\end{array}$} & \multicolumn{2}{|c|}{$\begin{array}{c}\text { Number of grains } \\
\text { /spike }\end{array}$} & \multicolumn{2}{|c|}{$\begin{array}{c}\text { 1000-grain weight } \\
(\mathrm{g})\end{array}$} \\
\hline & $2011 / 12$ & $2012 / 13$ & $2011 / 12$ & $2012 / 13$ & $2011 / 12$ & $2012 / 13$ \\
\hline \multicolumn{7}{|c|}{ A: Irrigation (I) } \\
\hline $\mathrm{I}_{1}$ (One) & 372.17 & 377.67 & 57.83 & 66.13 & 48.88 & 51.79 \\
\hline $\mathrm{I}_{2}$ (Two) & 408.71 & 418.50 & 64.29 & 68.67 & 54.63 & 56.43 \\
\hline$I_{3}$ (Three) & 429.67 & 441.33 & 69.08 & 74.25 & 57.66 & 60.31 \\
\hline F-test & ** & $\star \star$ & ** & ** & ** & $\star \star$ \\
\hline Reduction $\left(\mathrm{I}_{1}\right) \%$ & 15.45 & 16.86 & 19.45 & 12.28 & 17.96 & 16.45 \\
\hline Reduction $\left(\mathrm{I}_{2}\right) \%$ & 5.13 & 5.46 & 7.45 & 8.13 & 5.55 & 6.87 \\
\hline LSD 0.05 & - & - & - & - & - & - \\
\hline 0.01 & 4.01 & 4.34 & 2.26 & 1.56 & 2.15 & 2.00 \\
\hline \multicolumn{7}{|c|}{ B: Sowing methods (M) } \\
\hline Broadcasting & 369.50 & 420.92 & 63.38 & 69.75 & 50.03 & 56.15 \\
\hline Drilling & 405.42 & 387.00 & 60.04 & 65.38 & 53.25 & 51.57 \\
\hline Beds & 435.63 & 429.58 & 67.79 & 73.92 & 57.91 & 60.81 \\
\hline F- test & ** & ** & ** & ** & ** & ** \\
\hline LSD 0.05 & - & - & - & - & - & - \\
\hline 0.01 & 3.14 & 2.94 & 2.10 & 2.45 & 1.30 & 1.56 \\
\hline \multicolumn{7}{|c|}{ C: Cultivars (V) } \\
\hline Gemmeiza- 11 & 410.94 & 421.78 & 70.22 & 80.33 & 61.39 & 64.12 \\
\hline Misr- 1 & 430.72 & 437.22 & 60.50 & 59.78 & 52.82 & 55.06 \\
\hline Shandaweel- 1 & 380.11 & 402.11 & 55.94 & 63.56 & 43.41 & 46.44 \\
\hline Sids- 12 & 392.28 & 388.89 & 68.28 & 75.06 & 57.29 & 59.07 \\
\hline F-test & ** & ** & $\star \star$ & ** & ** & ** \\
\hline LSD 0.05 & - & - & - & - & - & - \\
\hline 0.01 & 3.48 & 3.59 & 1.98 & 2.32 & 1.29 & 1.43 \\
\hline \multicolumn{7}{|c|}{ D: Interactions effects } \\
\hline $1 \times M$ & ** & ** & NS & NS & * & NS \\
\hline$I \times V$ & ** & ** & ** & * & ** & 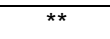 \\
\hline$M \times V$ & ** & ** & NS & NS & ** & NS \\
\hline$I \times M \times V$ & NS & NS & NS & NS & NS & NS \\
\hline
\end{tabular}

and "means significant at 0.05 and 0.01 levels of Probability, respectively, while NS means non significant

A significant effects of irrigation regimes were found on harvest index and protein content Table 5. Three irrigations showed the highest values of harvest index in both seasons (38.35 and $40.01 \%$ ). On contrast, increasing of irrigation decreased protein content \% since, one irrigation showed the 
maximum grain protein content (12.80 and $12.53 \%)$ compared to three irrigations (11.08 and $11.00 \%)$. Several investigators reported that drought stress reduced photosynthesis and translocation rates and increased respiration, which reduced available assimilates for grain filling and finally decreased grain yield. These results are in agreement with those obtained by Moghaddam et al. (2012), Ngwako and Mashiqa (2013) and El- Hag, Walaa (2015).

Table 4 :Effects of irrigation numbers, sowing methods and wheat cultivars and its interactions on grain weight/spike (g), grain yield (ardab/fad), straw yield (ton/fad) and biological yield (ton/ fad) during the two seasons 2011/12 and 2012/13.

\begin{tabular}{|c|c|c|c|c|c|c|c|c|}
\hline \multirow{2}{*}{\begin{tabular}{|l|}
\multicolumn{2}{|c}{ Characters } \\
Treatments \\
\end{tabular}} & \multicolumn{2}{|c|}{$\begin{array}{l}\text { Grain weight/ } \\
\text { Spike (g) }\end{array}$} & \multicolumn{2}{|c|}{$\begin{array}{l}\text { Grain yield } \\
\text { (ardab/fad) }\end{array}$} & \multicolumn{2}{|c|}{$\begin{array}{c}\text { Straw yield } \\
\text { (ton/fad) }\end{array}$} & \multicolumn{2}{|c|}{\begin{tabular}{|c|}
$\begin{array}{c}\text { Biological yield } \\
\text { (ton/ fad) }\end{array}$ \\
\end{tabular}} \\
\hline & $2011 / 12$ & $2012 / 13$ & $2011 / 12$ & $2012 / 13$ & 2011/12 & $2012 / 13$ & $2011 / 12$ & $2012 / 13$ \\
\hline \multicolumn{9}{|c|}{ A: Irrigation (I) } \\
\hline$L_{1}$ (One) & 3.02 & 3.88 & 19.46 & 21.32 & 5.08 & 4.96 & 8.00 & 8.16 \\
\hline$I_{2}$ (Two) & 3.41 & 4.18 & 21.60 & 22.67 & 5.67 & 6.26 & 8.91 & 9.66 \\
\hline$I_{3}$ (Three) & 3.61 & 4.64 & 23.24 & 23.54 & 5.62 & 6.25 & 9.11 & 9.78 \\
\hline F- test & ** & $\star \star \star$ & $\star \star \star$ & $* *$ & $* *$ & $* *$ & $* *$ & $\star \star \star *$ \\
\hline Reduction $\left(\mathrm{I}_{1}\right) \%$ & 19.54 & 19.59 & 19.42 & 10.41 & 10.63 & 26.00 & 13.87 & 19.85 \\
\hline Reduction $\left(\mathrm{I}_{2}\right) \%$ & 5.87 & 11.00 & 7.60 & 3.84 & 0.89 & 0.16 & 2.24 & 1.24 \\
\hline LSD 0.05 & - & - & 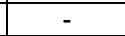 & - & - & - & - & 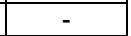 \\
\hline 0.01 & 0.26 & 0.41 & 0.82 & 1.48 & 0.48 & 0.48 & 0.45 & 0.41 \\
\hline \multicolumn{9}{|c|}{ B: Sowing methods (M) } \\
\hline Broadcasting & 3.12 & 4.15 & 20.13 & 21.15 & 5.44 & 5.58 & 8.46 & 8.75 \\
\hline Drilling & 3.39 & 4.13 & 21.25 & 22.18 & 5.42 & 5.62 & 8.61 & 9.25 \\
\hline Beds & 3.53 & 4.42 & 22.89 & 24.20 & 5.52 & 6.27 & 8.95 & 9.59 \\
\hline F- test & ** & * & ** & ** & NS & ** & ** & ** \\
\hline LSD 0.05 & - & 0.21 & - & - & - & - & - & - \\
\hline 0.01 & 0.17 & - & 1.09 & 1.44 & - & 0.40 & 0.37 & 0.40 \\
\hline \multicolumn{9}{|c|}{ C: Cultivars (V) } \\
\hline Gemmeiza- 11 & 3.81 & 4.51 & 23.22 & 24.54 & 5.44 & 6.10 & 8.92 & 9.78 \\
\hline Misr- 1 & 3.20 & 4.29 & 21.03 & 22.09 & 5.45 & 5.18 & 8.60 & 8.50 \\
\hline Shandaweel- 1 & 2.99 & 4.00 & 19.66 & 20.37 & 5.45 & 6.02 & 8.40 & 9.07 \\
\hline Sids-12 & 3.38 & 4.14 & 21.83 & 23.05 & 5.49 & 5.98 & 8.77 & 9.44 \\
\hline F- test & ** & ** & ** & ** & NS & ** & ** & ** \\
\hline LSD 0.05 & - & - & - & - & - & - & - & - \\
\hline 0.01 & 0.18 & 0.37 & 1.45 & 1.48 & - & 0.45 & 0.42 & 0.42 \\
\hline \multicolumn{9}{|c|}{ D: Interactions effects } \\
\hline $\mathrm{I} \times \mathrm{M}$ & * & 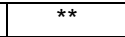 & * & NS & NS & ** & NS & ** \\
\hline $\mathrm{XVV}$ & NS & NS & NS & NS & NS & NS & NS & NS \\
\hline$M \times V$ & NS & NS & NS & * & NS & NS & NS & NS \\
\hline $\mathrm{I} \times \mathrm{M} \times \mathrm{V}$ & NS & NS & NS & NS & NS & NS & NS & NS \\
\hline
\end{tabular}

and "Significant at 0.05 and 0.01 levels of Probability, respectively, while NS means non Significant.

\section{B. Sowing methods effects (M).}

Results in Table 3 reveal that the bed method gave the highest number of spikes $/ \mathrm{m}^{2}(435.63$ and 429.58), respectively compared to broadcasting and drilling methods, the highest number of grains/spike (67.79 and73.92), followed by broadcasting method (63.38 and 69.75), respectively and gave the highest of 1000-grain weight (57.91 and 60.81g) compared to 
drilling method (53.25 and $51.57 \mathrm{~g}$ ) and broadcasting method (50.03 and $56.15 \mathrm{~g}$ ), respectively in both seasons, indicating that the three sowing methods behaved differently for these characters. Which might be the reduced the 1000-grain weight due to relatively, the less accumulation of dry matter in grains as compared with the others sowing methods and might have had subjected wheat plants to higher temperature during grain development stage. Also, bed planting prevented lodging of plants compared to broadcasting and led to increases in grain yield. These results are in harmony with Genedy (2014) and El - Hag, Walaa (2015).

Table 5: Effects of irrigation numbers, sowing methods, cultivars and their interactions on harvest index (\%) and grain protein content (\%) during the two seasons 2011/12 and 2012/13.

\begin{tabular}{|c|c|c|c|c|}
\hline \multirow{2}{*}{\begin{tabular}{|l} 
Characters \\
Treatments \\
\end{tabular}} & \multicolumn{2}{|c|}{ Harvest index (\%) } & \multicolumn{2}{|c|}{$\begin{array}{c}\text { Grain protein content } \\
(\%)\end{array}$} \\
\hline & $2011 / 12$ & $2012 / 13$ & $2011 / 12$ & $2012 / 13$ \\
\hline \multicolumn{5}{|c|}{ A: Irrigation (I) } \\
\hline$l_{1}$ (One) & 36.64 & 36.20 & 12.80 & 12.53 \\
\hline $\mathrm{I}_{2}$ (Two) & 36.50 & 35.32 & 12.57 & 12.41 \\
\hline$I_{3}$ (Three) & 38.35 & 40.01 & 11.08 & 11.00 \\
\hline F- test & * & ** & ** & ** \\
\hline LSD 0.05 & 1.59 & - & - & - \\
\hline 0.01 & - & 3.15 & 0.70 & 0.22 \\
\hline \multicolumn{5}{|c|}{ B: Sowing methods (M) } \\
\hline Broadcasting & 35.87 & 37.16 & 12.15 & 11.95 \\
\hline Drilling & 37.18 & 34.89 & 12.13 & 11.98 \\
\hline Beds & 38.44 & 39.48 & 12.16 & 12.01 \\
\hline F- test & * & ** & NS & NS \\
\hline LSD 0.05 & 2.04 & - & - & - \\
\hline 0.01 & & 2.62 & - & - \\
\hline \multicolumn{5}{|c|}{ C: Cultivars (V) } \\
\hline Gemmeiza-11 & 39.10 & 37.88 & 12.23 & 11.82 \\
\hline Misr-1 & 36.92 & 39.94 & 11.42 & 11.15 \\
\hline Shandaweel-1 & 35.17 & 33.88 & 13.02 & 12.86 \\
\hline Sids-12 & 37.47 & 37.00 & 11.92 & 12.08 \\
\hline $\mathrm{F}$ - test & ** & ** & ** & ** \\
\hline LSD 0.05 & - & - & - & - \\
\hline 0.01 & 2.98 & 2.96 & 0.55 & 0.24 \\
\hline \multicolumn{5}{|c|}{ D: Interactions effects } \\
\hline $1 \times M$ & NS & ** & NS & NS \\
\hline $\mathrm{I} \times \mathrm{V}$ & NS & ** & NS & NS \\
\hline $\mathrm{M} \times \mathrm{V}$ & NS & NS & NS & NS \\
\hline $\mathrm{I} \times \mathrm{M} \times \mathrm{V}$ & NS & NS & NS & NS \\
\hline
\end{tabular}

and" Significant at 0.05 and 0.01 levels of Probability, respectively, while NS means non Significant.

Results in Table 4 showed that, bed method gave the highest grain weight /spike (3.53and $4.42 \mathrm{~g}$ ) compared to broadcasting and drilling methods the highest values of grain yield (22.89 and $24.20 \mathrm{ardab} / \mathrm{fad}$ ) bed sowing method increased wheat grain yield by 13.71 and $7.72 \%$ in $2011 / 12$ and by 14.42 and $9.11 \%$ in 2012/13, comparable with broadcasting and drilling sowing methods respectively. Straw yield (5.52 and 6.27 ton/fad) however, the difference did not reach significant level in 2011/12 season. 
Straw yield was increased by 1.47 and $1.84 \%$ in $2011 / 12$ and by 12.37 and $11.57 \%$ in $2012 / 13$, under bed sowing method, comparable with broadcasting and drilling ones, respectively. And biological yield (8.95 and $9.59 \mathrm{ton} / \mathrm{fad}$ ) in both seasons, respectively. Biological yield seemed to follow the grain yield trend, where bed sowing method increased biological yield by 5.79 and $3.95 \%$ in $2011 / 12$ and by 9.60 and $3.68 \%$ in 2012/13,comparable with broadcasting and drilling sowing methods, respectively. The superiority of grain yield and its components of wheat plants, grown after cotton as preceding crop are due to the increase of growth attributes. Furthermore differences in types of the root distribution and hence the requirements of moisture and nutrients and consequently, the amounts absorbed by the root of preceding crops played a great role in this respect. The increase of grain yield may be due to the favourable environmental conditions erevailling during the growth was reflected on metabolites synthesis and consequently yield components, i.e. number of spike $/ \mathrm{m}^{2}$, number of grains /spike, grain weight /spike as well as 1000- grain weight and ultimately grain yield/fad.

Beds sowing method recorded that the highest harvest index in both seasons (38.44 and $39.48 \%$ ), respectively Table 5 . Also, Beds sowing markedly increased protein content percentage up to $12.16 \%$ and $12.01 \%$ in both seasons, respectively, as compared with the other methods of sowing. Hossain et al. (2009) reported that higher harvest index was observed in bed sowing over conventional with Shatabdi variety which showed a greater grain yield biomass ratio as a result to the advantage of bed planting. These results were similar to those obtained by Genedy (2014) and El- Hag, Walaa (2015).

C. Wheat cultivars performance (V).

Results in Table 3 showed that Misr-1 gave the highest number of spikes/ $\mathrm{m}^{2}(430.72$ and 437.22$)$.While, the wheat cultivar Gemmeiza-11 significantly exceeded the other cultivars concerning with number of grains/spike (70.22 and 80.33 ) and produced the highest 1000-grain weight (61.39 and64.12g), followed by Sids-12 (57.29 and $59.07 \mathrm{~g}$ ), then Misr$1(52.82$ and $55.06 \mathrm{~g})$, respectively in both seasons. The wheat cultivar Shandweel-1 was the least in this respect ( 43.41 and $46.44 \mathrm{~g}$ ). These results due to its a genetic character specific to the cultivar and the differences may be due to variability among the wheat cultivars under study which considered adequate for further biometrical assessment. These results are in harmony with those obtained by Abd El-Kreem and El-Hussin (2013) and El- Hag, Walaa (2015).

Results in Table 4 showed that the wheat cultivar Gemmeiza-11 significantly exceeded the tested wheat cultivars in all the studied characters. Gemmeiza-11 gave the highest values of grain weight / spike (3.81 and 4.51 g), grain yield (23.22 and $24.54 \mathrm{ardab} / \mathrm{fad}$ ), straw yield (5.44 and 6.10 ton/ fad) and biological yield (8.92 and 9.78 ton / fad) in both seasons, respectively. The differences among cultivars might be attributed to their variation in genetic make-up and to the unsteady environmental conditions. The recorded differences could be attributed to variations among the tested cultivars with respect to number of spikes $/ \mathrm{m}^{2}, 1000$ - grain weight, number of grains/spike and grain weight /spike. 
A significant effects of wheat cultivars on harvest index were found in both seasons Table 5. Maximum harvest index (39.10\%) was produced by Gemmeiza- 11 in 2011/12, season. While Misr-1 recorded that the highest harvest index (39.94\%) in the second season 2012/13. The wheat cultivar Shandweel-1 recorded that the highest grain protein content (13.02 and $12.86 \%$ ) while, Misr-1 gave the lowest one (11.42 and $11.15 \%$ ) in the first and second seasons, respectively. The drought stress reduced available assimilates for grain filling and finally decreased yield components i.e. number of spikes $/ \mathrm{m}^{2}$, number of grains per spike and straw yield / fad. which reflected decreases in grain yield / fad.). These results agreed with those reported by Ngwako and Mashiqa (2013) and El- Hag, Walaa (2015).

Table 6: Effects of interactions between (irrigation numbers, sowing methods and cultivars) on number of spikes $/ \mathrm{m}^{2}$, number of grains/spike and 1000-grain weight (g).

\begin{tabular}{|c|c|c|c|c|c|c|c|c|c|}
\hline Characters & \multicolumn{6}{|c|}{ Number of spikes $/ \mathrm{m}^{2}$} & \multicolumn{3}{|c|}{1000 -grain weight $(\mathrm{g})$} \\
\hline \multirow{3}{*}{$\begin{array}{l}\text { Sowing } \\
\text { methods (M) }\end{array}$} & \multicolumn{6}{|c|}{ Irrigation numbers (I) } & \multirow{2}{*}{\multicolumn{3}{|c|}{\begin{tabular}{|l} 
Irrigation numbers (I) \\
$2011 / 12$
\end{tabular}}} \\
\hline & \multicolumn{3}{|c|}{ 2011/12 } & \multicolumn{3}{|c|}{$2012 / 13$} & & & \\
\hline & $I_{1}$ & $I_{2}$ & $I_{3}$ & $I_{1}$ & $I_{2}$ & $I_{3}$ & $I_{1}$ & $I_{2}$ & $I_{3}$ \\
\hline $\mathrm{M}_{1}$ & 341.00 & 371.25 & 396.25 & 382.00 & 439.50 & 441.25 & 45.25 & 51.33 & 53.50 \\
\hline $\mathrm{M}_{2}$ & 377.38 & 408.50 & 430.38 & 345.25 & 376.00 & 439.75 & 48.86 & 54.54 & 56.34 \\
\hline$M_{3}$ & 398.13 & 446.38 & 462.38 & 405.75 & 440.00 & 443.00 & 52.54 & 58.04 & 63.15 \\
\hline \multirow{2}{*}{\begin{tabular}{|l} 
LSD 0.05 \\
0.01
\end{tabular}} & \multicolumn{3}{|c|}{5.25} & \multicolumn{3}{|c|}{4.90} & \multicolumn{3}{|c|}{2.16} \\
\hline & \multicolumn{3}{|c|}{8.69} & \multicolumn{3}{|c|}{8.11} & \multicolumn{3}{|c|}{3.57} \\
\hline \multirow{4}{*}{$\begin{array}{l}\text { Cultivars } \\
\text { (V) }\end{array}$} & \multirow{2}{*}{\multicolumn{6}{|c|}{$\begin{array}{l}\text { Number of spikes } / \mathrm{m}^{2} \\
\text { Irrigation numbers (I) }\end{array}$}} & \multirow{3}{*}{\multicolumn{3}{|c|}{$\begin{array}{l}\text { 1000-grain weight }(\mathrm{g}) \\
\text { Irrigation numbers }(\mathrm{l}) \\
2011 / 12\end{array}$}} \\
\hline & & & & & & & & & \\
\hline & \multicolumn{3}{|c|}{$2011 / 12$} & \multicolumn{3}{|c|}{$2012 / 13$} & $2011 / 12$ & & \\
\hline & $\mathrm{I}_{1}$ & $I_{2}$ & $I_{3}$ & $I_{1}$ & $\mathrm{I}_{2}$ & $I_{3}$ & $\mathrm{I}_{1}$ & $\mathrm{I}_{2}$ & $I_{3}$ \\
\hline$V_{1}$ & 380.17 & 416.00 & 436.67 & 393.33 & 427.33 & 444.67 & 54.79 & 61.54 & 67.83 \\
\hline$V_{2}$ & 405.83 & 435.67 & 450.67 & 418.00 & 440.00 & 453.67 & 48.43 & 54.24 & 55.78 \\
\hline$V_{3}$ & 342.67 & 386.33 & 411.33 & 358.00 & 410.00 & 438.33 & 40.09 & 44.32 & 45.83 \\
\hline $\mathrm{V}_{4}$ & 360.00 & 396.83 & 420.00 & 341.33 & 396.67 & 428.67 & 52.23 & 58.43 & 61.21 \\
\hline \multirow{2}{*}{$\begin{array}{l}\text { LSD } 0.05 \\
0.01\end{array}$} & \multicolumn{3}{|c|}{5.56} & \multicolumn{3}{|c|}{5.77} & \multicolumn{3}{|c|}{2.11} \\
\hline & & 8.42 & & & 8.74 & & & 3.19 & \\
\hline & & & nber of $g$ & ains/spik & & & $1000-8$ & rain we & ght (g) \\
\hline Cul & & & gation $\mathrm{n}$ & mbers (I) & & & Irrigat & on numb & ers (I) \\
\hline & & $2011 / 12$ & & & $2012 / 13$ & & & $2012 / 13$ & \\
\hline & $\mathrm{I}_{1}$ & $\mathrm{I}_{2}$ & $\mathrm{I}_{3}$ & $\mathrm{I}_{1}$ & $\mathrm{I}_{2}$ & $\mathrm{I}_{3}$ & $\mathrm{l}_{1}$ & $\mathrm{I}_{2}$ & $\mathrm{I}_{3}$ \\
\hline$V_{1}$ & 63.33 & 69.33 & 78.00 & 76.67 & 78.00 & 86.33 & 57.96 & 63.63 & 70.78 \\
\hline$V_{2}$ & 55.67 & 61.50 & 64.33 & 55.33 & 61.00 & 63.00 & 50.74 & 56.26 & 58.19 \\
\hline$V_{3}$ & 50.67 & 57.33 & 59.83 & 60.67 & 63.00 & 67.00 & 43.22 & 47.27 & 48.83 \\
\hline $\mathrm{V}_{4}$ & 61.67 & 69.00 & 74.17 & 71.83 & 72.67 & 80.67 & 55.24 & 58.55 & 63.42 \\
\hline LSD 0.05 & & 3.18 & & & 3.73 & & & 2.31 & \\
\hline 0.01 & & 4.81 & & & 5.65 & & & 3.50 & \\
\hline & & & mber of & pikes $/ \mathrm{m}^{2}$ & & & $1000-8$ & rain we & ght (g) \\
\hline Cult & & $2011 / 12$ & & & 2012/13 & & & $2011 / 12$ & \\
\hline & $\mathrm{M}_{1}$ & $\mathrm{M}_{2}$ & $\mathrm{M}_{3}$ & $\mathrm{M}_{1}$ & $\mathrm{M}_{2}$ & $\mathrm{M}_{3}$ & $\mathrm{M}_{1}$ & $\mathrm{M}_{2}$ & $\mathrm{M}_{3}$ \\
\hline $\mathrm{V}_{1}$ & 379.17 & 412.83 & 440.33 & 430.33 & 399.33 & 435.67 & 57.93 & 61.05 & 65.18 \\
\hline $\mathrm{V}_{2}$ & 402.83 & 433.33 & 456.00 & 442.00 & 421.00 & 448.67 & 48.68 & 51.65 & 58.12 \\
\hline$V_{3}$ & 340.00 & 382.00 & 418.33 & 412.33 & 371.00 & 423.00 & 40.88 & 43.17 & 46.19 \\
\hline$V_{4}$ & 356.00 & 393.50 & 427.33 & 399.00 & 356.67 & 411.00 & 52.61 & 57.11 & 62.15 \\
\hline LSD 0.05 & & 5.56 & & & 5.77 & & & 2.11 & \\
\hline 0.01 & & 8.42 & & & 8.74 & & & 3.19 & \\
\hline
\end{tabular}




\section{Interaction between the studied traits.}

Highly significant interactions were found between irrigation and wheat cultivars (I.xV.) concerning with the previous components in both seasons. Table 6 . While, significant interactions were found between irrigation $x$ sowing methods (I.XM.) and sowing methods $x$ wheat cultivars (M.XV.) concerning with number of spikes $/ \mathrm{m}^{2}$ in both seasons. The interactions between irrigation treatment and sowing methods $(I \times M)$ concerning with grain weight/spike $(\mathrm{g})$ in both seasons, grain yield (ardab/fad) in the first season 2011/12, straw yield (ton/fad) and biological yield (ton/ fad) in the second season only Table 7.

Table 7: Effects of interactions between (irrigation numbers, sowing methods and cultivars) on grain weight/spike (g), grain yield (ardab/fad), straw yield (ton/fad) and biological yield (ton/ fad).

\begin{tabular}{|c|c|c|c|c|c|c|c|c|c|c|}
\hline Characters & \multicolumn{7}{|c|}{ Grain weight/spike (g) } & \multicolumn{3}{|c|}{$\begin{array}{l}\text { Grain yield } \\
\text { (ardab/fad) }\end{array}$} \\
\hline \multirow{3}{*}{$\begin{array}{l}\text { Sowing } \\
\text { methods } \\
(\mathrm{M}) \\
\end{array}$} & \multicolumn{7}{|c|}{ Irrigation numbers (I) } & \multirow{2}{*}{\multicolumn{3}{|c|}{$\begin{array}{c}\text { Irrigation numbers (I) } \\
2011 / 12\end{array}$}} \\
\hline & \multicolumn{3}{|c|}{$2011 / 12$} & \multicolumn{4}{|c|}{$2012 / 13$} & & & \\
\hline & $I_{1}$ & $I_{2}$ & $I_{3}$ & $I_{1}$ & & $\mathbf{I}_{2}$ & $I_{3}$ & $l_{1}$ & $I_{2}$ & $I_{3}$ \\
\hline$M_{1}$ & 2.62 & 3.26 & 3.48 & 4.0 & & 4.18 & 4.22 & 17.26 & 20.90 & 22.30 \\
\hline $\mathrm{M}_{2}$ & 3.14 & 3.42 & 3.61 & 4.0 & & 4.17 & 4.19 & 19.95 & 21.53 & 22.27 \\
\hline$M_{3}$ & 3.29 & 3.55 & 3.74 & 3.5 & & 4.20 & 5.50 & 21.17 & 22.37 & 25.15 \\
\hline \multirow{2}{*}{\begin{tabular}{|l} 
LSD 0.05 \\
0.01
\end{tabular}} & \multicolumn{3}{|c|}{\begin{tabular}{l|l}
0.27 \\
0.27
\end{tabular}} & \multicolumn{4}{|c|}{0.47} & \multicolumn{3}{|c|}{1.80} \\
\hline & \multicolumn{3}{|c|}{0.45} & \multicolumn{4}{|c|}{0.78} & \multicolumn{3}{|c|}{2.98} \\
\hline \multirow{4}{*}{$\begin{array}{l}\text { Sowing } \\
\text { methods } \\
(\mathrm{M})\end{array}$} & \multicolumn{3}{|c|}{$\begin{array}{c}\text { Straw yield } \\
\text { (ton/fad) }\end{array}$} & \multicolumn{4}{|c|}{$\begin{array}{l}\text { Biological yield } \\
\text { (ton/fad) }\end{array}$} & \multicolumn{3}{|c|}{$\begin{array}{l}\text { Grain yield } \\
\text { (ardab/fad) }\end{array}$} \\
\hline & \multicolumn{3}{|c|}{\begin{tabular}{|c|} 
Irrigation numbers \\
(I)
\end{tabular}} & \multirow{2}{*}{\multicolumn{3}{|c|}{$\begin{array}{c}\begin{array}{c}\text { Irrigation } \\
\text { numbers }\end{array} \\
2012 / 13\end{array}$}} & \multirow[t]{3}{*}{$\begin{array}{c}\text { Cultivars } \\
\text { (V) }\end{array}$} & \multicolumn{3}{|c|}{$\begin{array}{l}\text { Sowing methods } \\
\text { (M) }\end{array}$} \\
\hline & \multicolumn{3}{|c|}{$2012 / 13$} & & & & & \multicolumn{3}{|c|}{$2012 / 13$} \\
\hline & $I_{1}$ & $I_{2}$ & $I_{3}$ & $I_{1}$ & $I_{2}$ & $\mathbf{I}_{3}$ & & $\mathbf{M}_{1}$ & $M_{2}$ & $\mathbf{M}_{3}$ \\
\hline $\mathrm{M}_{1}$ & 4.07 & 6.35 & 6.32 & 7.01 & 9.58 & 9.65 & $\mathrm{~V}_{1}$ & 23.68 & 23.13 & 26.81 \\
\hline $\mathrm{M}_{2}$ & 4.84 & 6.03 & 5.99 & 8.33 & 9.66 & 9.77 & $\mathrm{~V}_{2}$ & 20.74 & 22.68 & 22.84 \\
\hline$M_{3}$ & 5.97 & 6.39 & 6.44 & 9.13 & 9.73 & 9.91 & $\mathrm{~V}_{3}$ & 18.93 & 20.85 & 21.32 \\
\hline \multirow{3}{*}{$\begin{array}{l}\text { LSD } 0.05 \\
0.01\end{array}$} & \multicolumn{3}{|c|}{0.71} & \multicolumn{3}{|c|}{0.71} & $V_{4}$ & 21.27 & 22.05 & 25.85 \\
\hline & \multirow{2}{*}{\multicolumn{3}{|c|}{1.17}} & \multirow{2}{*}{\multicolumn{3}{|c|}{1.17}} & LSD 0.0 & \multirow{2}{*}{\multicolumn{3}{|c|}{$\frac{2.38}{3.61}$}} \\
\hline & & & & & & & 0.01 & & & \\
\hline
\end{tabular}

Significant interactions were found between irrigation treatment $x$ sowing method (IxM) and irrigation $x$ varieties (IxV) Table 8 concerning with harvest index in the second season. El- Hag, Walaa (2015) concluded that, interaction between cultivars and irrigation treatment had highly significant effects on number of spikes $/ \mathrm{m}^{2}$, number of grains/spike, straw and grain yield, while it was insignificant for harvest index and 1000- grain weight.

Simple correlation coefficients analysis:

Simple correlation coefficients between grain yield/fad. and yield attributes over treatments and seasons are presented in Table 9. The Results indicated that, number of spikes $/ \mathrm{m}^{2}$, number of grains/spike, 1000-grain weight, grain weight/spike, straw yield (ton/fad), biological yield (to/ fad), harvest index and grain protein content had the greatest influence on grain 
yield/fad. Another correlation worthy of some attention is that between number of spikes $/ \mathrm{m}^{2}$ and each of number of grains/spike, 1000-grain weight, grain weight/spike, straw yield (ton/fad), biological yield (ton/ fad), harvest index and grain protein content. Also positive and highly significant relationships were found between number of grains/spike and 1000-grain weight, grain weight/spike, straw yield (ton/fad), biological yield (ton/ fad), harvest index and grain protein content. As well as, between 1000-grain weight and each of grain weight/spike, straw yield (ton/fad), biological yield (ton/ fad), harvest index and grain protein content.

Table 8: Effects of interactions between (irrigation numbers, sowing methods and cultivars) on harvest index (\%) in 2012/13 season.

\begin{tabular}{|c|c|c|c|c|c|c|c|}
\hline \multirow{3}{*}{$\begin{array}{l}\text { Sowing } \\
\text { methods (M) }\end{array}$} & \multirow{2}{*}{\multicolumn{3}{|c|}{$\begin{array}{c}\text { Harvest index (\%) } \\
\text { Irrigation numbers (I) } \\
2012 / 13\end{array}$}} & \multirow{3}{*}{$\begin{array}{c}\text { Cultivars } \\
\text { (V) }\end{array}$} & \multirow{2}{*}{\multicolumn{3}{|c|}{$\begin{array}{c}\text { Harvest index (\%) } \\
\frac{\text { Irrigation numbers (I) }}{2012 / 13}\end{array}$}} \\
\hline & & & & & & & \\
\hline & \multicolumn{3}{|c|}{\begin{tabular}{|l|l|l}
$I_{1}$ & $I_{2}$ & $I_{3}$
\end{tabular}} & & $I_{1}$ & $I_{2}$ & $I_{3}$ \\
\hline$\overline{M_{1}}$ & 34.71 & 33.85 & 42.93 & $\mathrm{~V}_{1}$ & 38.75 & 36.35 & 38.54 \\
\hline $\mathrm{M}_{2}$ & 35.16 & 34.58 & 34.92 & $V_{2}$ & 36.60 & 36.80 & 46.42 \\
\hline$M_{3}$ & 38.73 & 37.55 & 42.17 & $\mathrm{~V}_{3}$ & 34.01 & 32.63 & 35.00 \\
\hline \multirow{3}{*}{$\begin{array}{l}\text { LSD } 0.05 \\
0.01\end{array}$} & \multicolumn{3}{|c|}{4.35} & $\mathrm{~V}_{4}$ & 35.42 & 35.51 & 40.07 \\
\hline & \multirow{2}{*}{\multicolumn{3}{|c|}{7.20}} & \multirow{2}{*}{$\begin{array}{c}\text { LSD } 0.05 \\
0.01\end{array}$} & \multicolumn{3}{|c|}{4.77} \\
\hline & & & & & & 7.22 & \\
\hline
\end{tabular}

Results clearly indicated that, grain weight/spike showed significant and positive correlation with straw yield (ton/fad), biological yield (ton/ fad), harvest index and grain protein content. Also straw yield (ton/fad) revealed that highly significant and positively correlated with biological yield (ton/ fad), harvest index and grain protein content. A highly significant and positive relationship appeared between biological yield (ton/ fad) and harvest index and grain protein content. It is clear that there were significant and positive correlations between harvest index and grain protein content. These results are in agreement with Gehan et al., (2011).

Table 9: Matrix of simple correlation coefficients among wheat grain yield and its attributing variables (over treatments and seasons).

\begin{tabular}{|c|c|c|c|c|c|c|c|c|c|}
\hline Characters & 1 & 2 & 3 & 4 & 5 & 6 & 7 & 8 & 9 \\
\hline 1.Grain yield. & 1.000 & & & & & & & & \\
\hline 2. Number of spikes $/ \mathrm{m}^{2}$. & $0.853^{* *}$ & 1.000 & & & & & & & \\
\hline 3. Number of grains/spike. & $0.970^{* *}$ & $0.331^{* *}$ & 1.000 & & & & & & \\
\hline 4. 1000-grain weight $(\mathrm{g})$. & $0.889^{\star *}$ & $0.400^{\star *}$ & $0.869^{* *}$ & 1.000 & & & & & \\
\hline 5. Grain weight/spike (g). & $0.663^{\star *}$ & $0.426^{\star *}$ & $0.583^{* *}$ & $0.394^{* \star}$ & 1.000 & & & & \\
\hline 6. Straw yield (ton/fad.). & $0.909^{* *}$ & $0.370^{* *}$ & $0.411^{* *}$ & $0.517^{* *} C$ & $0.345^{* *}$ & 1.000 & & & \\
\hline 7. Biological yield (ton/ fad.). & $0.857^{\star \star}$ & $0.615^{\star \star}$ & $0.752^{* *}$ & $0.822^{* *}$ & $0.491^{\star *}$ & $\star 0.648^{\star \star}$ & 1.000 & & \\
\hline 8. Harvest index (\%). & $0.689^{* *}$ & $0.673^{\star *}$ & $0.681^{* *}$ & $0.735^{\star *} C$ & $0.805^{\star \star}$ & $\star 0.565^{\star \star}$ & *0.743** & 1.000 & \\
\hline 9. Grain protein content (\%). & $0.789^{* *}$ & $0.429^{* *}$ & $0.815^{\star *}$ & $0.761^{* *}$ & 0.217 & $0.536^{* *}$ & $0.488^{* *}$ & $0.301 *$ & 1.000 \\
\hline
\end{tabular}




\section{REFERENCES}

Abd El-Kreem,Thanaa, H. A. and G.G. A. El-Hussin (2013). Evaluation of Four New Bread Wheat (Triticum aestivum L.) Cultivars in Sandy Soils under Different Irrigation Regimes and Nitrogen Fertilizer Rates for Yield and Its Components. Alex. J. Agric. Res., 58(3):241-250.

Abdelraouf, R. E.; S. F. El Habbasha and M .H. Taha (2013). Effect of irrigation water requirements and fertigation levels on growth, yield and water use eficiency in wheat. Refaie Middle-East Journal of Scientific Research, 16 (4): 441-450.

Ali, M.; L. Ali; M. Q. Waqar and M. A. Ali (2012). Bed planting: A new crop establishment method for wheat (Triticum aestivum L.) Int. J. Agric. Appl. Sci., 4(1): 834-841.

Awad, H. A. (2001). Effect of irrigation water deficit and seed rates on wheat yield under salt-affected soil. J. Agric. Sci. Mansoura Univ., 26(2): 487-495.

Coventry, D.R.; R.K. Gupta ; A. Yadav ; R.S. Poswal ; R.S. Chhokar and Cummins, J.A.(2011). Wheat quality and productivity as affected by varieties and sowing time in Haryana. India F. Cr. Res., 123: 214-225.

El-Hag, Walaa, A.A. (2015). Morphological Studies on Bread Wheat under Different Regimes and Planting Methods. Ph D.Thesis, Fac. of Agric. Kaferelshikh Univ., Egypt.

Gehan, A.M. Amin, H.G. Geweifel, M.A. Gomaa, M. A. El-kholy and Magda, $H$. Mohamed (2011). Effect of sowing methods and fertilization on yield analysis and grain quality of wheat under new reclaimed sandy soil. Journal of Applied Sciences Research, 7(12): 1760-1767.

Genedy, M. S. A. (2014). Effect of some planting methods, nitrogen fertilization rates and irrigation on wheat grain yield. Ph D. Thesis, Mansoura Univ., Egypt.

Hossain, M. I.; K. D. Sayre; R.K. Gupta; J. M. Duxbury; and M. E. Haque (2009). Performance of different wheat genotypes under different tillage options. Int. j. Sustain. Crop Prod., 4(6): 17-21.

James, L.G. (1988). Principles of Farm Irrigation System Design. PP.106128. John Wiley\& Sons, New York.

Kearsey, M.J. and H.S Pooni. (1996). The genetical analysis of quantitative traits. $1^{\text {st }}$ edition. Chapman and Hall, London, pp 381.

Moghaddam H. A.; M. Galavi; M. Soluki; B. Siahsar; S. M. M. Nik and M. Heidari (2012). Effects of deficit irrigation on yield, yield components and some morphological traits of wheat cultivars under field conditions. Int. J. Agric. Res. and Rev., 2: 825-833.

Moussa, A.M. and H.H. Abd El-Maksoud (2004). Effect of soil moisture regime on yield and its components and water use efficiency for some wheat cultivars. Annals Agric. Sci., Ain Shams Univ., 49 (2): 515-530.

Moustafa, M. A.; L. Boersma and W. E. Kronstad (1996). Response of four spring wheat cultivars to drought stress. Crop Sci., 36: 982-986. 
Ngwako S. and P. K. Mashiqa (2013). The effect of irrigation on the growth and yield of winter wheat (Triticum aestivum L.) cultivars. Int. J. Agri., Crop Sci., 5 (9): 976-982.

Salem, Nagwa R.A. ; G.A. El-Shaarawy and H.H. Abd El-Maksoud (2006). Performance of two bread wheat cultivars under different irrigation regimes. Egypt. J. Sci., 21(12): 60-82.

Sayre, K.D. and O.H. Ramos (1997). Applications of raised- bed planting systems to wheat.Wheat Program Special Report No.31. Mexico, DF: CIMMYT.

Snedecor, G.W. and W.G. Chochran (1981). "Statistical Methods" $6^{\text {th }}$ Edn., lowa State Univ. Press, lowa, USA.

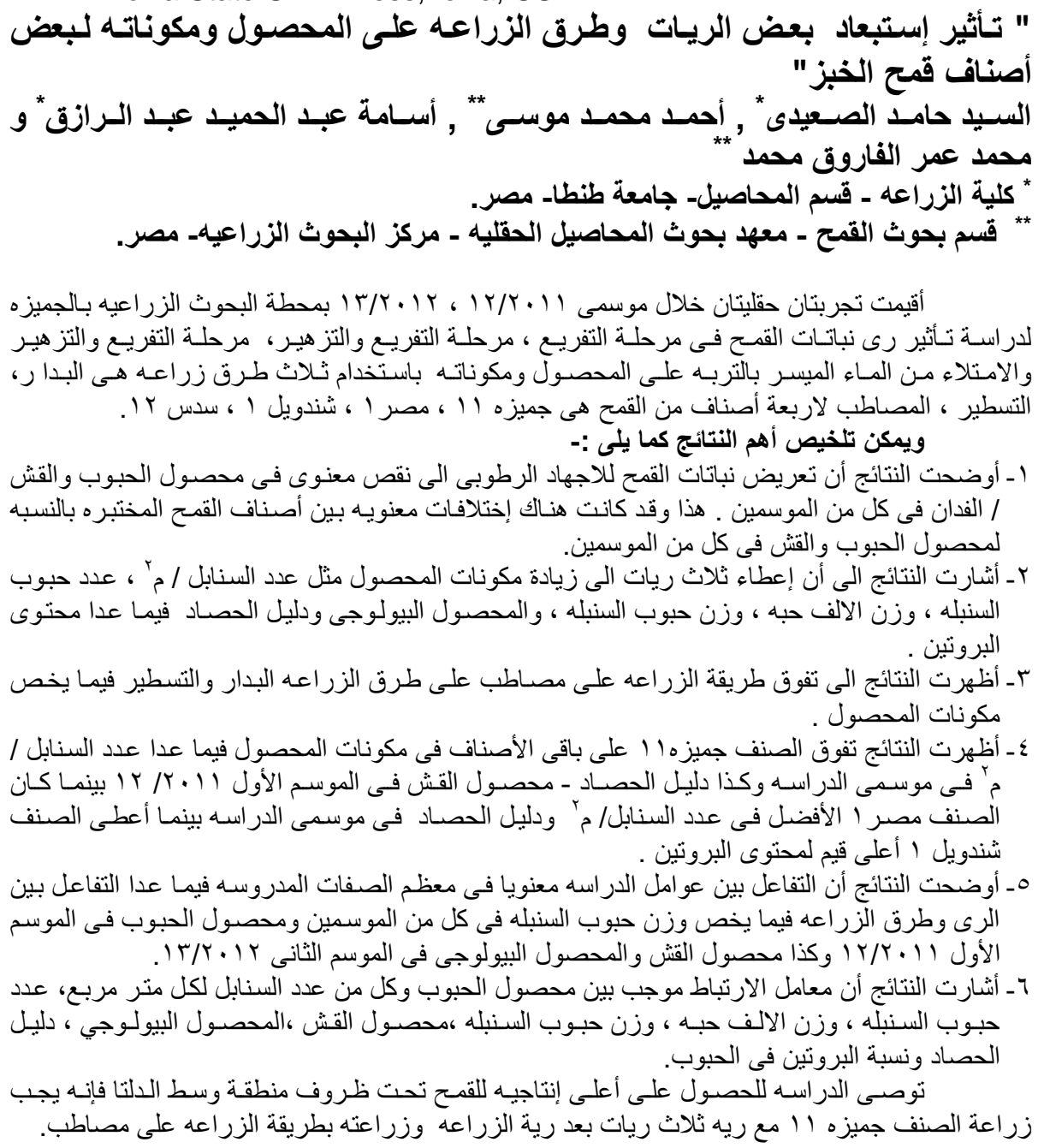

